Original Research Paper

\title{
Upaya Pemanfaatan Limbah Buah Semangka Sebagai Alternatif Pupuk Organik Untuk Mengurangi Pencemaran Lingkungan Di Desa Pringgabaya
}

\author{
Muh. Zubair ${ }^{1}$, Nadia Rizkiana ${ }^{1}$, Syafaatun Khaironi ${ }^{1}$, Rika Ayu Cahyaningrum ${ }^{2 *}$, Rasikah Diah Pratiwi ${ }^{3}$, \\ Muhammad Yusril Alawi ${ }^{4}$ \\ ${ }^{I}$ Manajemen, Fakultas Ekonomi dan Bisnis Universitas Mataram, Mataram, Indonesia; \\ ${ }^{2}$ Ilmu Komunikasi, Fakultas Ilmu Sosial dan Ilmu Politik, Universitas Mataram, Mataram, Indonesia; \\ ${ }^{3}$ Agribisnis, Fakultas Pertanian, Universitas Mataram, Mataram, Indonesia; \\ ${ }^{4}$ Ilmu Hukum, Fakultas Hukum, Universitas Mataram, Mataram, Indonesia;
}

https://doi.org/10.29303/jpmpi.v3i2.891

Sitasi: Zubair, M., Rizkiana, N., Khoironi, S., Cahyaningrum, R. A., Pratiwi, R. D., \& Alawi, M. Y. (2021). Upaya Pemanfaatan Limbah Buah Semangka Sebagai Alternatif Pupuk Organik Untuk Mengurangi Pencemaran Lingkungan

Di Desa Pringgabaya. Jurnal Pengabdian Magister Pendidikan IPA, 4(3)

\author{
Article history \\ Received: 15 Juli 2021 \\ Revised: 31 Juli 2020 \\ Accepted: 18 Agustus 2021 \\ *Corresponding Author: Rika \\ Ayu Cahyaningrum, Ilmu \\ Komunikasi, Fakultas Ilmu \\ Sosial dan Ilmu Politik, \\ Universitas Mataram, Mataram, \\ Indonesia; \\ Email: \\ rikaayucahya@gmail.com
}

\section{Pendahuluan}

Indonesia dikenal sebagai negara agraris. Hal ini tidak lain karena sebagian besar penduduknya bekerja di sektor pertanian dengan skala persentase sebesar 88,57 pada tahun 2020 . Sektor pertanian merupakan salah satu penopang perekonomian Indonesia. Selanjutnya khususnya di Provinsi Nusa Tenggara Barat, jumlah penduduk yang berprofesi sebagai petani sebanyak 98,24 persen. Dengan tingginya persentase jumlah penduduk yang berprofesi sebagai petani ini juga menyebabkan permintaan akan ketersediaan pupuk juga akan meningkat, baik itu pupuk organik maupun anorganik.

Pupuk organik adalah pupuk yang berperan dalam meningkatkan aktivitas biologi, kimia, dan fisik tanah sehingga tanah menjadi subur dan baik untuk pertumbuhan tanaman (Indriani, 2004). Pupuk organik terdapat dalam bentuk padat dan

\begin{abstract}
Penelitian ini menganalisis tentang upaya pemanfaatan limbah buah semangka sebagai alternatif pupuk organik untuk mengurangi digunakan dalam penelitian ini seperti botol beks ukuran standar, selang gas, dan buah semangka yang sudah tidak layak dikonsumsi (rusak). Hasil dari penelitian Pupuk Organik Cair (POC) berdampak positif karena dapat mengurangi pencemaran lingkungan dan berpotensi menyuburkan tanah. member penggunaan $P O C$ juga menyebabkan pengeluaran petani untuk membeli pupuk anorganik bisa dikurangi, sehingga menyebabkan biaya
\end{abstract}

Keywords: Petani; Pencemaran Lingkungan; POC.

cair. Kelebihan pupuk organik cair adalah unsur hara yang terdapat di dalamnya lebih mudah diserap tanaman (Murbandono, 1990). Pada umumnya pupuk cair organik tidak merusak tanah dan tanaman meskipun digunakan sesering mungkin. Selain itu, pupuk cair juga dapat dimanfaatkan sebagai aktivator untuk membuat kompos (Lingga dan Marsono, 2003). Pupuk organik cair dapat dibuat dari beberapa jenis sampah organik yaitu sampah sayur baru, sisa sayuran basi, sisa nasi, sisa ikan, ayam, kulit telur, sampah buah seperti anggur, kulit jeruk, apel, semangka, dan lain lain.

Namun, saat ini sebagian besar petani masih bergantung pada pupuk kimia anorganik. Namun penggunaan pupuk anorganik secara terus menerus dapat menimbulkan dampak negatif terhadap lingkungan, khususnya kondisi tanah. Penggunaan pupuk anorganik dapat menyebabkan tanah menjadi cepat mengeras, kurang mampu menyimpan air dan cepat menjadi asam yang pada 
akhirnya menurunkan produktivitas tanaman (Ramdhani, 2010) dan akan berdampak pada pencemaran lingkungan.

Secara umum, pencemaran lingkungan adalah masuk atau dimasukkannya makhluk hidup, zat, energi atau komponen lain ke dalam lingkungan atau berubahnya tatanan lingkungan akibat kegiatan manusia atau proses alam. Sehingga kualitas lingkungan turun sampai ke tingkat tertentu yang menyebabkan lingkungan menjadi kurang atau tidak dapat berfungsi lagi sesuai peruntukannya. Untuk itu, diperlukan sebuah langkah konservatif guna meminimalisir pencemaran lingkungan tersebut.

Desa Pringgabaya terkenal memiliki pantai yang indah yaitu pantai ketapang yang konon katanya pantai ini merupakan tempat bagi masyarakat Pringgabaya melakukan upacara kebudayaan yaitu Rebo Bontong, Desa Pringgabaya juga memiliki tanah yang gembur dan sangat cocok untuk bertani namun pemandangan akan sampah atau limbah yang mencemari lingkungan banyak terlihat di setiap titik jalan. Hal tersebut dapat merusak pemandangan dan mengganggu penciuman masyarakat yang melintas di sekitar area tersebut. Oleh karena itu, agar limbah bisa menjadi bermanfaat, kami mahasiswa Universitas Mataram ingin membantu mengurangi limbah sampah tersebut khususnya limbah dari buah semangka untuk dijadikan sebagai bahan pembuatan pupuk organik cair. Pemanfaatan pupuk organik cair ini diharapkan dapat membantu petani agar tidak ketergantungan menggunakan pupuk anorganik dan meminimalisir pencemaran lingkungan.

\section{Metode}

Penelitian ini dilaksanakan pada hari Senin, bulan juli 2021 di Dusun Belawang Daye, Desa Pringgabaya, Kecamatan Pringgabaya, Kabupaten Lombok Timur, NTB.

\section{1) Alat dan bahan}

Alat yang dibutuhkan dalam penelitian ini adalah botol bekas ukuran standar, selang, dan buah semangka yang sudah tidak layak dikonsumsi (rusak). Bahan yang akan digunakan dalam penelitian ini adalah buah semangka yang tidak layak dikonsumsi. Karena buah semangka yang busuk mengandung mikrobakteri. Mikroba Bakteri dalam pertanian bermanfaat untuk: a) Memfiksasi nitrogen dari atmosfer,

b) Dekomposisi sampah dan residu organik sehingga lebih aman untuk lingkungan,

c) Menekan patogen tular tanah,

d) Meningkatkan ketersediaan hara,

e) Degradasi racun yang berasal dari pestisida atau bahan kimia lainnya,

f) Menghasilkan antibiotik dan bahan aktif lainnya,

g) Menghasilkan molekul bahan organik sederhana untuk diserap tanaman,

h) Meningkatkan kompleksitas logam berat sehingga tidak dapat diserap oleh tanaman dan

i) Melarutkan hara yang tidak terlarut (Higadan Parr, 1994; Berg,2009; Simarmata, 2013).

2) Lokasi penelitian

Dusun Belawang Daye, Desa Pringgabaya, Kecamatan Pringgabaya, Kabupaten Lombok Timur, Nusa Tenggara Barat (NTB).

3) Populasi dan sampel

Populasi yang digunakan dalam penelitian ini adalah seluruh warga di dusun Belawang Daye sedangkan sampel yang digunakan adalah 30 orang warga Dusun Belewang Daye Desa Pringgabaya Kecamatan Pringgabaya Lombok Timur, Nusa Tenggara Barat.

4) Jenis penelitian

Penelitian ini bersifat kualitatif dengan menggunakan metode eksperimen. Penelitian Kualitatif adalah penelitian yang bersifat deskriptif dan cenderung menggunakan analisis. Proses dan makna (perspektif subjek) lebih ditonjolkan dalam penelitian kualitatif . Landasan teori dimanfaatkan sebagai pemandu agar fokus penelitian sesuai dengan fakta di lapangan. Desain eksperimen merupakan suatu proses pengujian yang bertujuan untuk memperoleh suatu hasil dari perubahanperubahan variabel-variabel input dan mengidentifikasi perubahan dari output (Sudjana, 1994). Desain eksperimen mempunyai arti suatu proses rancangan percobaan sedemikian rupa sehingga informasi-informasi yang dibutuhkan dari penelitian dapat diperoleh dan dikumpulkan. Desain eksperimen itu sendiri berfungsi untuk melihat hasil terbaik dari beberapa eksperimeneksperimen yang telah dilakukan setelah diuji terlebih dahulu. Desain eksperimen yang digunakan adalah rancangan acak lengkap (RAL). RAL 
diartikan sebagai suatu eksperimen di mana kita hanya mempunyai sebuah faktor yang nilainya berubah- ubah.Faktor yang diperhatikan dapat memiliki sejumlah taraf dengan nilai yang bisa kuantitatif, kualitatif, bersifat tetap maupun acak (Sudjana, 1994). Rancangan Acak Lengkap (RAL) pada pengerjaannya memerlukan beberapa perlakuan untuk melihat perbandingan dari masingmasing percobaan itu sendiri. Pada percobaan yang menggunakan RAL hasil terbaik akan diambil dari beberapa percobaan yang telah dilakukan.

5) Pelaksanaan Penelitian

Lokasi pengambilan buah semangka diambil dari pasar Pringgabaya, Desa Pringgabaya, Kecamatan Pringgabaya, Kabupaten Lombok Timur, buah semangka yang diambil sebanyak 7 buah dengan berbagai macam ukuran.

\section{Hasil dan Pembahasan}

Kulit semangka kaya akan mineral dan kandungan air yang tinggi sehingga masih berguna dan banyak manfaatnya. Klasifikasi tanaman semangka dapat dijabarkan sebagai berikut:

Kingdom : plantae

Divisio : Magnoliopsida

Classis : Magnoliopsida

Ordo : violales

Familia : Cucurbitaceae

Genus : Citrullus

Spesies : Citrullus vulgaris

Kulit semangka yang saat ini belum dimanfaatkan secara maksimal oleh masyarakat dapat dimanfaatkan sebagai pupuk untuk mengurangi permasalahan sampah yang dapat menyebabkan pencemaran. Kandungan air dalam kulit semangka per $100 \mathrm{~g}$ sebesar 87,7, kandungan karbohidrat yaitu 5,6 g, kandungan protein yaitu 2,5 $\mathrm{g}$, kandungan lemak yaitu $0,1 \mathrm{~g}$, kandungan kalsium yaitu $8 \mathrm{mg}$, kandungan vitamin A yaitu 2845, kandungan vitamin C yaitu 7,63 mg, kandungan fosfor yaitu $11 \mathrm{mg}$ dan kandungan kalium yaitu $220 \mathrm{mg}$. (USDA, 2015). Dapat dilihat dari gambar dibawah ini, hasil dari POC setelah disemprotkan pada tanaman cabai petani yang ada di Belawongdaye, desa Pringgabaya.

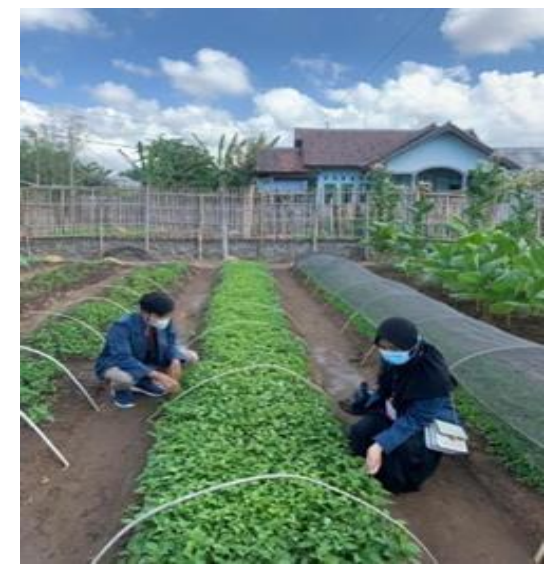

Gambar 1. Pengaplikasian pupuk organik cair ke tanaman warga

Unsur-unsur yang terkandung dalam kulit semangka ini membuat kulit semangka berpotensi untuk dimanfaatkan sebagai pupuk organik.Pemberian pupuk organik cair (POC) kulit semangka pada konsentrasi $15 \mathrm{ml} / \mathrm{L}$ dapat meningkatkan pertumbuhan pada tanaman.

Adapun cara pembuatan pupuk organik dari semangka yaitu Buah semangka dipotong terlebih dahulu dengan cara memisahkan kulit semangka dengan isinya. Kemudian isinya yang sudah busuk tersebut diperas untuk mengambil air sarinya. Setelah itu, air sarinya dimasukan ke dalam botol plastik ukuran standar, dengan cara tutup botol plastik tersebut diberi lubang dan dimasukan selang. Hal tersebut dilakukan agar air sari buah semangka yang di taruh dalam botol selama tiga hari tidak meledak dan tidak kedap udara. Pengolahan buah semangka selama beberapa hari ini disebut dengan cara fermentasi. Hal ini bertujuan untuk menguraikan senyawa-senyawa yang terdapat dalam 3 bahan yang digunakan, dan bertujuan agar mudah diserap oleh tanaman. Proses fermentasi membutuhkan waktu yang cukup lama. Berikut merupakan contoh dari limbah semangka yang sudah difermentasi dan siap untuk digunakan.

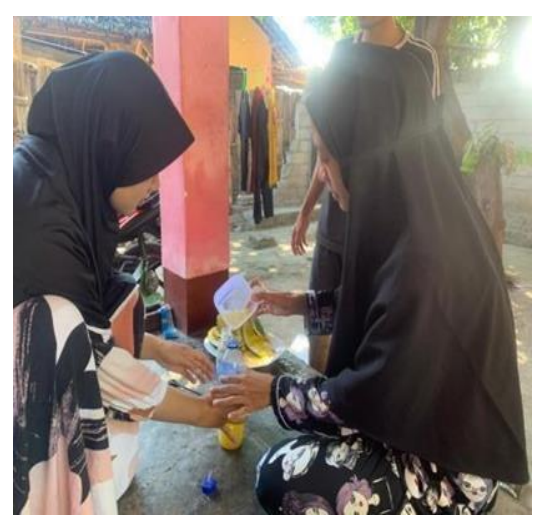


Gambar 2. Proses pembuatan POC dari Limbah Semangka

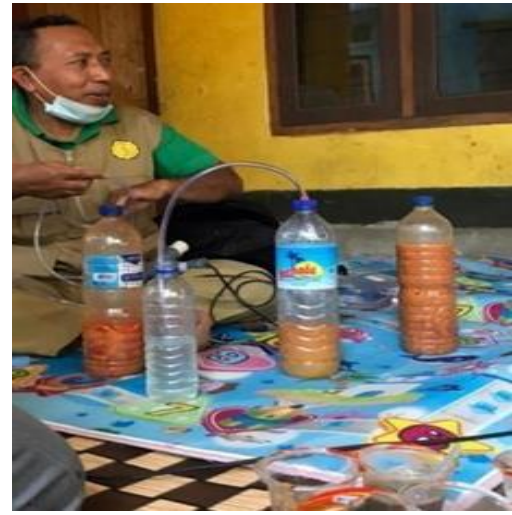

Gambar 3. Hasil Fermentasi

Pupuk organik cair (POC) kulit semangka dengan lama kematangan 2 minggu yaitu memiliki unsur nitrogen $(\mathrm{N})$ sebanyak $0.09 \%$, fosfor $(\mathrm{P})$ sebanyak $0.12 \%$, kalium (K) sebanyak $0.34 \%$, air sebanyak $97.4 \%$, protein sebanyak $0.37 \%$, lemak sebanyak 6\%, dan karbohidrat sebanyak $6 \%$. Sedangkan pupuk organik cair (POC) kulit semangka dengan lama kematangan 4 minggu yaitu memiliki unsur nitrogen (N) sebanyak $0.07 \%$, fosfor $(\mathrm{P})$ sebanyak $0.08 \%$, kalium $(\mathrm{K})$ sebanyak $0.30 \%$, air sebanyak $97.5 \%$, protein sebanyak $0.10 \%$, lemak sebanyak $5 \%$, dan karbohidrat sebanyak $3.8 \%$

Ciri-ciri fisik dari POC kulit semangka yaitu dilihat dari warna, bau, dan kepekatan. Warna POC kulit semangka umur 2 minggu tidak terlalu coklat pekat, sedangkan warna POC kulit semangka umur 4 minggu sama-sama berwarna coklat tetapi lebih gelap karena lebih lama difermentasi, itu menandakan bahwa POC yang berumur 4 minggu sudah matang. Bau POC kulit semangka umur 2 minggu masih agak berbau, sedangkan bau POC kulit semangka umur 4 minggu sudah tidak berbau lagi dan baunya lebih mirip ke bau tape, jika sudah tidak berbau maka POC sudah matang. Kepekatan POC kulit semangka umur 2 minggu encer artinya sudah sesuai dengan POC yang sudah matang, dan kepekatan POC kulit semangka umur 4 minggu juga encer artinya sudah sesuai juga dengan POC yang sudah matang.Jika dibandingkan hasil analisis kandungan unsur hara POC kulit semangka dengan Peraturan Menteri Pertanian No 70/Permentan/Sr.140/10/2011,maka hasilnya kurang sesuai. Kadar unsur hara nitrogen $(\mathrm{N})$ POC kulit semangka umur 2 minggu menunjukkan hanya mengandung $0.09 \%$ dan di umur 4 minggu mengandung nitrogen $(\mathrm{N})$ hanya $0.07 \%$, sedangkan pada Peraturan Menteri Pertanian No.70 harus 3$6 \%$, artinya kadar nitrogen kurang banyak dibutuhkan pada POC kulit semangka. Nitrogen Itu sendiri merupakan unsur hara utama yang sangat dibutuhkan oleh tanaman.

Adapun jumlah pertanyaan untuk mengukur keberhasilan penelitian ini tentang pengaruh penggunaan pupuk organik cair (POC) terhadap hasil pertanian masyarakat dan dampak terhadap pencemaran lingkungan yang terdiri atas 10 pertanyaan dan jumlah responden sebanyak 30 orang. Selanjutnya jawaban dari pertanyaan terhadap responden dikategorikan dengan opsi A yaitu YA dan opsi B yaitu Tidak. Dapat dilihat dari tabel di bawah ini.

Tabel 1. Hasil Responden terhadap penggunaan POC sebagai pengganti pupuk anorganik berdampak positif terhadap pengurangan pencemaran lingkungan

\begin{tabular}{|c|l|c|c|}
\hline \multirow{2}{*}{ No } & \multicolumn{1}{|c|}{ Pertanyaan } & \multicolumn{2}{|c|}{ Keterangan } \\
\cline { 2 - 4 } & \multicolumn{1}{|c|}{ YA } & TIDAK \\
\hline 1. & Apakah POC yang diberikan sudah digunakan? & 17 & 13 \\
\hline 2. & Apakah terlihat adanya pengaruh dari POC saat penyemprotan terhadap tanaman? & 18 & 12 \\
\hline 3. & Apakah anda senang menggunakan POC? & 17 & 13 \\
\hline 4. & Apakah terdapat keinginan untuk berganti jenis pupuk yaitu POC? & 19 & 11 \\
\hline 5. & Apakah menurut anda pembuatan POC itu mudah? & 17 & 13 \\
\hline 6. & $\begin{array}{l}\text { Apakah menggunakan POC lebih menguntungkan dibandingkan dengan pupuk } \\
\text { anorganik? }\end{array}$ & 19 & 11 \\
\hline
\end{tabular}




\begin{tabular}{|c|l|c|c|}
\hline 7. & Apakah POC baik untuk digunakan secara berkelanjutan? & 30 & 0 \\
\hline 8. & $\begin{array}{l}\text { Apakah anda sudah melakukan remake (pembuatan ulang) POC setelah } \\
\text { penyuluhan? }\end{array}$ & 12 & 18 \\
\hline 9. & Apakah menurut anda POC bisa dikatakan unggul dibandingkan jenis pupuk lainnya? & 18 & 12 \\
\hline 10. & Apakah anda merekomendasikan kepada petani lain untuk menggunakan POC? & 19 & 11 \\
\hline
\end{tabular}

Berdasarkan data diatas maka dapat disimpulkan bahwa penggunaan POC sebagai pengganti pupuk anorganik berdampak positif terhadap pengurangan pencemaran lingkungan. Tidak hanya itu penggunaan pupuk organik cair yang terbuat dari limbah semangka menguntungkan bagi petani, karena kualitas hasil tanam menjadi lebih baik dan tanah tetap terjaga kesuburannya. Selain itu penggunaan POC juga menyebabkan pengeluaran petani untuk membeli pupuk anorganik bisa dikurangi, sehingga menyebabkan biaya produksi lebih kecil namun laba yang dihasilkan meningkat.

\section{Kesimpulan}

Berdasarkan hasil dari penelitian yang telah dilaksanakan, maka dapat disimpulkan bahwa limbah dari buah semangka memiliki potensi sebagai pupuk organik cair (POC). Dengan pemanfaatan limbah buah semangka sebagai bahan utama dalam pembuatan pupuk organik cair (POC), maka diharapkan dapat menjadi salah satu alternatif untuk mengurangi volume limbah buah-buahan yang ada serta dapat digunakan sebagai pengganti pupuk kimia yang tentunya tidak baik untuk kondisi tanah yaitu dapat menyebabkan tanah menjadi cepat mengeras, kurang mampu menyimpan air dan cepat menjadi asam yang pada akhirnya menurunkan produktivitas tanaman.

\section{Ucapan Terima Kasih}

Terima kasih kami ucapkan kepada Dosen Pembimbing Lapangan yang sudah memberikan pengarahan terkait pelaksanaan Program Kerja Pupuk Organik oleh Mahasiswa KKN Tematik Universitas Mataram tahun 2021. Terimakasih kami ucapkan kepada seluruh aparat Desa Pringgabaya, Kecamatan Pringgabaya, Kabupaten Lombok Timur, serta Kepala Wilayah (KAWIL) Dusun Belawong Daye yang telah memfasilitasi terselenggaranya kegiatan penelitian ini dengan baik dari awal hingga selesai.

\section{Daftar Pustaka}

Christina, Chyntia, Rama R Sitinjak, dan Bayu Pratomo. 2021. Pengaruh Tingkat Kematangan POC Kulit Semangka (Citrullus Vulgaris Schard.) di Pembibitan Kelapa Sawit Pre Nursery. Jurnal Indonesia Sosial Teknologi. 2, 1123-1131. https://jist.publikasiindonesia.id/index.php/jist/a rticle/view/197/398 (diakses pada 29 Juli 2021).

Hadisuwito, S. 2007. Membuat Pupuk Kompos Cair. Redaksi AgroMedia Pustaka. Jakarta.ISBN 979006116-1

Nur, Muhammad. 2019. Analisis Potensi Limbah Buahbuahan Sebagai Pupuk Organik Cair. Seminar NasionalTeknik Industri Universitas Gadjah Mada.https://repository.ugm.ac.id/275331/1/ Analisis\%20Potensi\%20Limbah\%20Buahbuahan $\% 20$ Sebagai\%20Pupuk\%20Organik\%2 0Cair.pdf (diakses pada 29 Juli 2021).

Nur, Thoyib, Ahmad Rizali Noor, \& Muthia Elma. 2016. Pembuatan Pupuk Organik Cair dari Sampah Organik Rumah Tangga Dengan Penambahan Bioaktivator $\mathrm{EM}_{4}$. Konversi. 5, 5-12. https://media. neliti.com/media/publications/10 7634-ID-none.pdf (diakses pada 27 Juli 2021)

Roidah, I. A. 2013. Manfaat Penggunaan Pupuk Organik untuk Kesuburan Tanah. Jurnal Universitas Tulungagung Bonorowo Vol. 1. No. 1

Yuliani, Paulina. 2017. Pengaruh Lama Fermentasi Pupuk Cair Bayam, Sawi, Kulit Pisang, dan Kulit Semangka Terhadap Kandungan Fosfor dan Kalium Total Dengan Penambahan Bioaktivator $\quad \mathrm{EM}_{4}$. https://repository.usd.ac .id/9460/2/131434033_full.pdf (diakses pada 28 Juli 2021). 